\title{
Vurun Kahpeye ve Cemile Bağlamında Tip ve Karakterlerin Karşılaştırmalı İncelemesi
}

\author{
Kemal GÖZ ${ }^{1}$
}

$\ddot{O} z$

Bu çalışmada Halide Edip Adıvar'ın kaleme aldığ1 "Vurun Kahpeye” adlı roman "olumlu kahramanlar, belirtik ve örtük hakikat, kahramanın iç dünyasının açılımı ve yazarın eserine uzaklığı" açılarından ele alınmıș ve bu süreçte eser Cengiz Aytmatov tarafından kaleme alınan "Cemile" adlı romanla karşılaştırılmıştır. Aynı zamanda "olumlu kahramanlar” başlığı altında Özbek ve Kırgız edebiyatından da örnekler vererek Türk edebiyatında tip olarak tanımlanan terim ile olumlu kahraman olarak tanımlanan terim arasındaki farklar üzerinde durulmuştur. Kahramanın iç dünyasının açılımı ile ilgili karşılaştırmalı olarak verilen örnekler vasıtasıyla yapılan karşılaştırmalarda ise ilkesel olarak doğru olanın ne olduğu araştırılmıştır. "Yazarın eserine uzaklığı" konusu da irdelenerek karşılaştırması yapılan romanlar arasında sanatsal olarak bir değerlendirme yapılmıştır. Ayrıca makalede Halide Edip Adıvar'ın oluşturmaya çalıştığ1 varsayılan kolektif bellek üzerinde de durularak eserin bu yüzden "belirtik hakikate" yakın bir çizgide kaleme alındığı üzerinde durulmuş ve "Vurun Kahpeye" adlı eserin sanat değeri açısından bir yargıya varmaya çalışılmıştır.

Anabtar Kelimeler: Vurun Kahpeye, Halide Edip Adivar, Olumlu Kahramanlar, Zoşenko, Aytmatov, Jdanov

\section{Type and Character Analysis and Comparison With Regard to "Vurun Kahpeye" and} "Cemile"

\begin{abstract}
In this study the novel called "Vurun Kahpeye" which was written by Halide Edip Adivar, was emphasized in terms of positive characters, obvious and implicit reality, evolution of the inside world of the character and the distance of the writer to novel and in this process it was compared with the novel called "Cemile" which was written by Cengiz Aytmatov. At the some time the differences between the term which is defined as type and the term which is defined as positive character in Turkish literature giving examples from Uzbek and Kyrgyz literatures under the title of positive characters, were emphasized. Through the comparative examples and comparisons the question of principal truth was investigated in the character's inside world. An artistic evaluation was made among the evaluated novels by examining the subject of the distance of the writer to novel. Also, in the article the collective memory which was supposed to be formed by Halide Edip Adivar was emphasized because of this the novel was reality and it was tried to pass judgment on the artistic value of the novel called "Vurun Kahpeye".
\end{abstract}

Key Words: Vurun Kahpeye, Halide Edip Adıvar, Cengiz Aytmatov, Positive Characters, Jdanov, Zoşenko

\section{Atıf İçin / Please Cite As:}

Göz, K. (2020). Vurun Kahpeye ve Cemile bağlamında tip ve karakterlerin karşılaştırmalı incelemesi. Manas Sosyal Araștormalar Dergisi, 9(1), 539-551.

Geliş Tarihi / Received Date: 27.12.2018

Kabul Tarihi / Accepted Date: 06.06.2019

1 Dr. Öğr. Üyesi - Karamanoğlu Mehmetbey Üniversitesi Edebiyat Fakültesi, kemalgoz@kmu.edu.tr
ORCID: 0000-0003-4768-6604 


\section{Giriş}

Çağdaş Türk edebiyatı incelemelerinde olumlu kahramanlar terimi kullanılmamaktadır. Bu terim daha çok Sovyetler Birliği bünyesinde teşekkül eden edebiyatlarda meydana getirilen eserleri tenkit ederken ve incelerken kullanılır. Olumlu kahramanlar, Sovyetler Birliği edebiyatında esasında bilinçli olarak teşekkül ettirilmiştir. Bu kahramanlar toplumun her yönüyle örnek olarak kabul edebileceği, Sovyetlerin ortaya koyduğu ülküler doğrultusunda toplumu da arkasından götürebilecek kadar sağlam bir kişiliği olan, tek yönlü yalınkat kahramanlardır. Bunlar hem fiziksel olarak hem de ruhsal açıdan son derece mükemmel özelliklerle donatılmış yalınkatlar oldukları için yaşadıkları kurmaca dünyalarda bu kahramanların fizikî ya da ruhî açıdan bir eksikliklerine tesadüf etmek 1960’lı yllara kadar neredeyse mümkün olmamıştır.

\section{Kurmaca Dünyalardaki Tip ve Olumlu Kahramanlar Arasındaki Farklar}

Esasında kurmaca dünyalarda sürekli olarak yapılagelen tip-karakter ayrımında olumlu kahramanları "tip" olarak tarif etmek toplumcu gerçekçi edebiyat mantığı ile teșekkül ettirilmeyen diğer edebiyatlarda "tip" şeklinde tarif edilen diğer kurmaca dünya kişileri ile karışmalarına neden olabilir. Olumlu kahramanlar anladığımız manada "tip" olmadıkları gibi "karakter" de değillerdir. Karakter ve tip kavramlarının açıklanması ile "olumlu kahramanların" bunlardan ayrılan özelliklerine temas etmek gerekmektedir.

Kurmaca dünyalardaki karakterlerin bir farklıllğa sahip olması, bir derinliğe ulaşması gerekir. Karakter ne yapacağ1 tahmin edilemeyen zaman zaman okuru şaşırtabilecek kısacası karakter sahibi kişilerdir (Karataş, 2018, s. 183). Tipler ise kendi benliklerinin dışındaki değerleri temsil ederler. Genel toplumsal özelliklerle donatılmış, içsel gelişim ve değişimlerinden çok söz edilmeyen, daha çok dıştan görünüşleriyle ele alınan kurmaca dünya kişileridir (Belge, 1998, s. 21-22).

Yukarıda tarifi yapılan "karakter" ve "tip" temel alındığında olumlu kahramanların iki tarife de uyamadıklanı görülmektedir. Tip tanımında yapılan "kendi benliklerinin dışındaki değerleri temsil ederler" tarifi "olumlu kahramanları" anlatmaya yetmemektedir. Çünkü olumlu kahramanlar müstesna kişiliklerdir ve iyi yönde oluşturulmuş birçok farklı özellikleri ile toplumcu gerçekçi edebiyatın yüzünü topluma dönmüss askerleridir. Yine yukarıda yapılan karakter tanımındaki "karakter ne yapacağ1 tahmin edilemeyen zaman zaman okuru şaşırtabilecek kısacası karakter sahibi kişilerdir" değerlendirmesi de "olumlu kahramanlar" için söylenemez. Çünkü bir "olumlu kahramanın” ne yapacağı bellidir. Daha en baştan yazar tarafindan oluşturulma amacı toplumdaki ya üretim araçlarını sslah etmek (bir kolhozda üstün gayretle çalışarak diğer çiftçilere örnek olmak) ya eğitimin ışığını o 1şı̆̆ın hiç gitmediği yerlere götürerek gece gündüz çalışmak ya da halklar arası kardeşliğin simgesi olmaktır vs.

Diğer taraftan kurmaca dünya "tipleri”, "olumlu kahramanlar" gibi kurmaca dünyanın merkezinde yer almazlar. Toplumcu gerçekçi edebiyatta olay örgüsü "olumlu kahramanların" etrafında şekillenir ve gelişirken "tipler" için böyle bir iddiada bulunmak imkânsızdır. "Olumlu kahramanlar" bir ideayı yerine getirmek için var edilmişlerken "tiplerin” bir ideası yoktur. "Tipler" olay örgüsü içerisinde belirli bir görevi yerine getirirler ve olay örgüsünün merkezinden uzakta dururlar. "Olumlu kahramanların" ise önlerinde yazar tarafından konulmuş olan bir amaçları vardır, esasında bu amaç aynı zamanda yazarın da amacıdır. Fakat "tipler" kurmaca dünyanın merkezinden uzak oldukları için ve oluşturulma gerekleri farklı olduğundan dolayı olay örgüsünün üzerine yoğunlaştı̆̆1 amaçtan uzaktadırlar. Tiplerin farklı özellikleri olabilir. Kel, kısa boylu, içkici ya da hırsız vb. özelliklerin hepsini ya da bir kısmını üzerinde toplayabilirler. Ancak bir olumlu kahraman örnek bir güzelliğe, imrenilecek bir erdeme ve şaşılacak düzeyde ulvi bir ahlaka sahip olmak zorundadır. Çünkü önüne konulan kutsal amaca ancak bu özellikleri sayesinde ulaşması mümkündür.

\section{Olumlu Kahramanların İlk Örnekleri}

Olumlu Kahramanların ön belirtilerini ve toplumcu gerçekçi edebiyatın esaslarına ilk tesadüf edilen yer Platon'un "Devlet" adlı eseridir. Platon'un hocası Sokrates ve Glaukon'un bir devletin nasıl kurulabileceği ve toplumu oluşturan dinamikler üzerine girdikleri diyalogda Sokrates ilk olarak insan olgusu üzerinde durur ve devleti ayakta tutacak olan insan tipinin nasıl olması ve nasil yetiştirilmesi gerektiğine dair bazı varsayımlar ileri sürer.

Kültürel hafızanın önemini bilen ve kuracağı devletin zemini olarak insanı seçen Sokrates, kurmayı tasarladığı devletin "bekçilerinin" nasıl yetiştirilmesi gerektiği üzerinde düşünmüş ve şu sonuca varmıştı. Eğer "devletin bekçilerinin" yiğit olmaları isteniyorsa onlara ölümden elden geldiği kadar az korkmalarını 
sağlayacak sözler söylenmeli ve hatta Homeros ve başka şairlerin şiirlerindeki ölüm temalı dizeler çıkarılmalıydı:

"Bu ölmüs, bu sönmüs insanlara kral olmaktansa, yoksul bir ciftçinin yannda ırgat olmak daha bos gelir bana..." "Tanrlar bile ürküten o korkunc, o kokmus dünya ne ölümlülerin gözzüne görü̈sün ne de

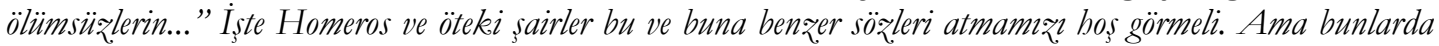
siï yok mu, duyan hoșlanmaz. mı bunlardan? Tersine, bunlar boșa giden sözler olduğu için, özgürliugü sevmesi kölelikten, ölümden kaçmmasi gereken insanlara duyurulmamal. (Platon, 2018, s. 72)

Yine "Devlette" Sokrates edebiyatın ister sözlü olsun ister yazılı insan hayatı ve davranışları üzerinde etkisi olduğunu ve bunu toplumların şekillendirilmeleri sırasında kullanılabileceğini şu satırlarla belirtmektedir:

"Bu masallar yasak etmeliyiz ki, genclerimiz kötü yollara sapmasin kolay kolay... Çünkï șairler, yazarlar, insanlar üstüne de doğru dürüst konuşmuyorlar. Masallarnda eğri insanlarn mutlu, doğrularn mutsuz. olduğunu görïyoru₹: Eğriliğini giz̨lemesini bilen türlï nimetlere kavusuyor; doğru insansa baskalarna yararl, kendine zararle oluyor. Bu çessit sö̈lleri de söyletmeyiz, sairlere; bunun tam tersini gösteren masallar anlatmalarm istemeliyiz değil mi??" (Platon, 2018, s. 82).

$\mathrm{Bu}$ bağlamda oluşturulan zeminin yapısının edebiyat ve sanatla olan yakın ilgisi milattan önceki tarihlerde bile bilinen bir gerçekti. Bu zeminin sanatçıların ilgisini çektiği gibi otoritelerin de dikkatini çekmiştir.

\section{Ahlaki Kölelik}

İvan Gonçarov'un romanı Oblomov (1859), “olumlu kahramanların” ortaya çıkması ve edebiyatta daha fazla kullanılması sürecinin önemli yapı taşlarından birisi olmuştur. Bunun böyle olmasında kuşkusuz ünlü eleştirmen Dobrolyubov tarafindan 1859 yilında kaleme alınan "Oblomovluk Nedir" adlı eleştiri yazısının etkisi olmuştur. "Oblomov" romanı ve "Oblomovluk Nedir" yazısı burada bir bütün olarak değerlendirildiğinde hem romanın hem de eleştiri yazısının değeri daha da artmaktadır. Yazısının başında "okudukları romanlarda bir takım toplumsal ayıpların kınanmasından hoşlanan okurların keyfini kaçırmıştı..." (Dobrolyubov, 1987, s. 17) cümleleri ile eleştirel gerçekçi edebiyatın üzerine kurulu olduğu zemini de eleştiren Dobrolyubov'un yazısı, ileride Rus edebiyatını etkileyecek bir mahiyette idi. Çünkü iki duyarlı sanat adamı içlerinden çıktıkları toplumun akış yönünü üstün bir hassasiyetle tespit etmişlerdi. Oblomov bir çiftlik sahibidir ama ekip dikme işlerinden anlamaz, hesap işleri Oblomov'un uğraşamayacağı kadar yorucudur ve bu konu ile ilgilenmez, kâhyasının gönderdiği hesapları kabullenir. Memuriyet hayatından kısa sürede ayrılır, başladığı her işten kısa sürede sıkılır ve bıkkınlık duyar. Oblomov Rus toplumuna has bir hastalıktır. Ve bu hastalığın adı Oblomovizm'dir. Oblomov görünüşte emir verendir ama emir verdiği uşağı Zahar’a zorla hiçbir şey yaptıramayacak kadar güçsüzdür. Zahar'ın istemediği hiçbir şeyi ona yaptıramaz yapmak istediği herhangi bir şeyi ise engelleyemez. Bu yüzden görünüşte uşak olan Zahar emir veren ise Oblomov'dur ama Oblomov isteklerini yerine getirmesi için farkında olmadan uşağı Zahar'ın kölesi hâline gelmiştir (Dobrolyubov, 1987, s. 39).

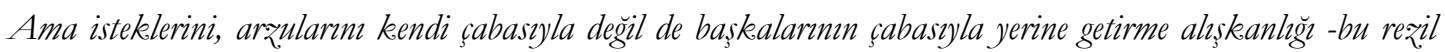

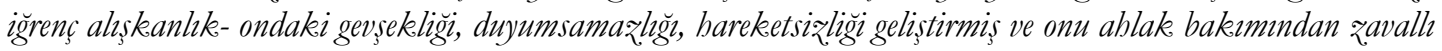
bir köle konumuna düsü̈rmüstür (Dobrolyubov, 1987, s. 38).

Oblomovizm'in panzehiri ise yine romanın içindeki başka bir karakter olan Ştolts'tur." 'Rus adları taşıyan daha kaç Ştolts gerek bize!' Bize daha pek çok Ştolts'un gerektiğine hiç kuşku yok." (Dobrolyubov, 1987, s. 83). Gonçarov Rus içtimai hayatını eleştirirken sı̆̆ bir bakış takınmamıştır. Gançarov'un başlangıçta pek anlaşılmayan bu derin kavrayışını arayıp bulan Dobrolyubov eleştirel gerçekçi edebiyatın eksik yönünü ve toplumcu gerçekçi edebiyatın ana ilkesini 1859 yllında şu satırlarla ifade etmiştir:

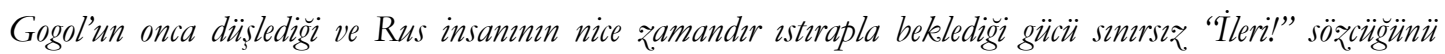
haykerarak bu insanlarn kim harekete geçirecek? (Dobrolyubov, 1987, s. 77).

İnsanları kimin nasıl harekete geçireceğinin ipuçlarını Gorki vermiştir. Maksim Gorki, Edebi Sapamlar'da (1934) devrim sürecinden bahsederken bunun bir kültür yaratma süreci olduğundan bahsetmekte ve bu sürecin özel mülkiyetlerin ortadan kaldırılması, toplumsal asalakllğın bütün biçimlerinin yok edilmesine dayalı bir süreç olduğundan bahsetmekteydi. Gorki'nin Sovyet yazarlarına burada yönlendirdiği en büyük eleştiri yukarıda bahsi geçen sürecin canlı gücü olan "insanın” yeteri kadar ele 
alınmaması, yüzeysel olarak çizilmesi, kayıtsızlık içinde değerlendirilmesiydi. (Gorki, 2011, s. 88) İnsanın boş, soğuk hayranlık sözcükleri ile anlatılmasına karşı çıkan ve insanın olanca gerçekliği ile yansıtılamamasını eleştiren Gorki gerçek sanatın abartma hakkına sahip olduğunu şu cümlelerle anlatmaktadir:

\begin{abstract}
Herküllerin, Prometeuslarm, Don Kişotlarn, Faustlarn birer fantęi ürünü olmayn, gerçek olaylarn tamamen meşru ve gerekli şïrsel abartmalar olduklarm genc yaz̧arlar anlamıyorlar. Biz̨im gerçek, canli kahramanımız, yani sosyalist kültürün yaratıcısı olan insanımı, roman ve bikâyelerimizdeki kahramanlardan çok daha büyük çok daha yücedir. Edebiyatta, bu insan olduğunda da büyük ve yüce gösterilmelidir (Gorki, 2011, s. 88).
\end{abstract}

Olumlu kahramanlar 1934 yılında toplanan yazarlar birliği kurultayında Stalin'in yakın adamlarından Jdanov tarafindan şu cümlelerle ifade edilmişlerdir:

"Biẓim ülkemizde edebiyatın asıl kahramanlar yeni hayatın aktif inşa edicileridir. Isşiler, kolhozlarda çalışan ciftçiler, köylüler, parti üyeleri, mühendisler, genc komünistler, komünist ögrencilerdir. Isste edebiyatımızdaki asıl tipler ve asıl kahramanlar bunlardir"(Jdanov, 1934, s. 4).

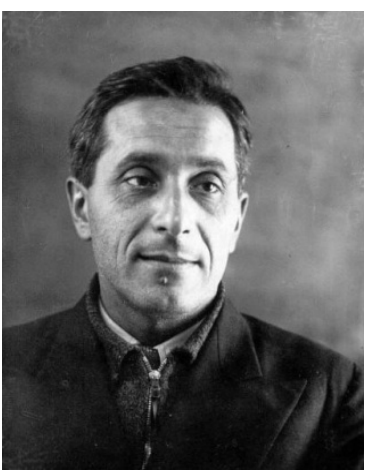

Resim 1. M.M. Zoşenko

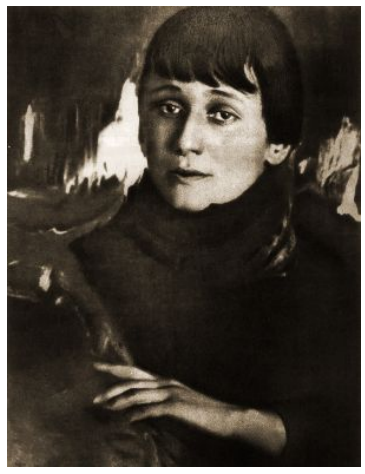

Resim 2. Anna Ahmatova

Dolayısıyla olması gereken ya da gelecekten gelen 1 şıkla aydınlatılan ideanın yansıtıldı̆̆ı toplumcu gerçekçi edebiyat eleştirel gerçekçilikten gerçekliğin tanımının ne olduğu konusunda ayrıldı̆̆ı gibi kurmaca dünyaların yansıttığı idealar bakımından da ayrılmıştır. Bu keskin ayrımın derinleştiği en önemli nokta ise yine Jdanov'un 1946'da (Say1 225, 21 Eylül) Pravda gazetesinde yayımlanan “'Zvezda ve Leningrad Dergilerine Dair Rapor" adlı makalesidir. Mihail Mihailoviç Zoşenko (1894-1958) ve Anna Ahmatova'nın (1899-1966) Zevzda (Y1ldı) ve Leningrad dergilerinde yayımlanan yazılar1 ile ilgili hem dergilerin yazı işlerini hem de adı geçen edebiyatçıları ağır bir dille eleştiren Jdanov özellikle Zoşenko'nun kaleme aldığı "Maymunun Serüvenleri" (Zvezda, 1946, s. 5-6) adlı kısa hikâye üzerinde vurgu yapmıştır. Toplumcu Gerçekçilik aynı zamanda yazarın içinde yaşadığı topluma yabancılaşmasına, toplumdan tiksinmesine ve onu kıyasıya eleştirmesine de tepki idi. "Maymunun Serüvenleri”"nde hikâye savaşın yeni başladığı bir dönemde şehirdeki hayvanat bahçesine düşen bir bombanın birçok hayvanın ölmesine neden olması ve diğer hayvanlar arasından en cesaretlisi olan maymunun da yıkılan duvarlar arasından kaçarak şehir içinde dolaşmaya başlamasını anlatıyor.

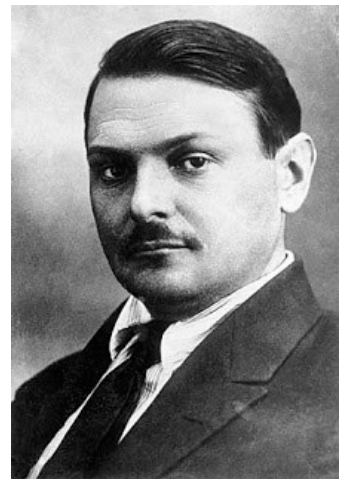

Resim 3. A. A. Jdanov

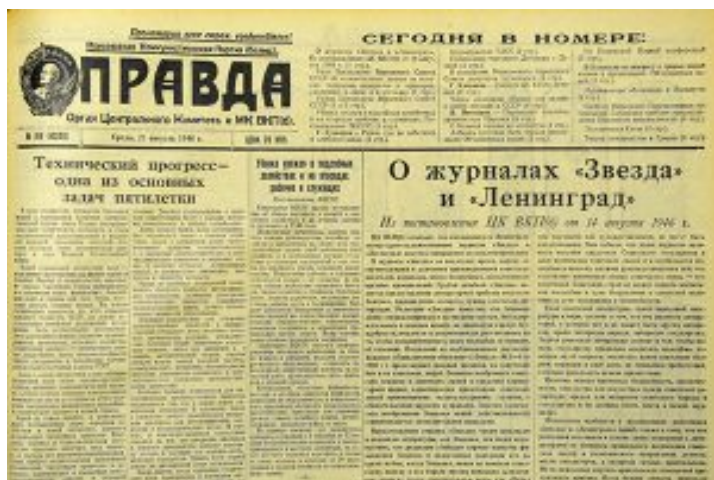

Resim 4. Jdanov'un yazısı, Pravda gazetesi 
Jdanov yazısının bir bölümünde:

"Zosenko Soryet Insanm tembel, kaba, ilkel, aptal ve çirkin olarak tasvir ediyor, kesinlikle ama kesinlikle Soyyet insanmmn kahramanliğg, emeği ve toplumsal manada yüksek moral düzeyi ve yüce gönüllï̈̆̈̈ Zossenko'yu ilgilendirmiyor. Bu konular onun eserlerinde asla bulamazsını. Terbiyesiz, ve dar kafal Zoșenko yaşamm en önemsiz ve basit yanlarm bulup bunlarn kendisine devaml konu edinmekte. Ve bu ayrnticllk. esasinda bir rastlantı değil, bunu Zoșenko da dâbil olmak üzere bütün aşağgllke ve dar kafal yazarlar yapmaktalar" (Jdanov, 1952, s. 3).

Satırlarıyla toplumla barışık olmayan topluma yabancılaşan eleştirel gerçekçi edebiyatı sert bir şekilde eleştiriyor ve küçük ayrıntıları kendisine konu edinerek bilinçli olarak toplumda eleştirecek yön aradığını düşündüğü Zoşenko ve benzeri yazarların bir daha yazmalarını engelleyecek derecede sert konuşuyordu. Aynı yazı da Anna Ahmatova'yı ise "değersiz kişisel yaşantılarını" sanata taşımakla suçlayan Jdanov, kimseye faydası olmayan, kendisini ve doğal olarak Sovyet okurlarını da ilgilendirmeyen şahsî deneyimlerini ahlaksızlık olarak suçlamış ve sanatta tek amacın topluma yön verecek bir amaç olması gerektiğini belirtmişti. Sanat yoluyla bireyin kendini ifade etmesi en azından belli bir dönem "toplumsal gerçekçi" edebiyat için gereksiz ve zararlı olarak görüldü.

\section{Türk Edebiyatı'nda Olumlu Kahramanlar Var mıdır?}

Roman ve uzun hikâyelerin olay örgüleri içerisinde "olumlu kahramanlar" parti tarafından oluşturulan kutsal amacına ulaşabilmek için her türlü olumsuzlukla savaşan, yeri geldiği zaman en doğal insanî özelliklerden dahi ülküsü adına vazgeçebilen, yorulmak bilmeyen savaşçlar olarak karşımıza çıkmıştır. Olumlu kahramanların yazarlar tarafından abartılan bu özellikleri olay örgüsü içerisindeki çatışmada karşılarına fon olarak mecburî surette çıkarılan kötü yalınkatların da tam tersi mahiyette uç düzeylerde fiziksel ve ruhî olumsuzluklarla donanmasına neden olmuştur.

Halide Edip Adıvar'ın "Vurun Kahpeye" adlı romanı olumlu kahramanlar konusuna Türk edebiyatından örnek verebilmek için uygun bir eserdir. Genç bir muallime olan Aliye tayinini 1srarla Anadolu'ya ister ve öğretmen olarak tayin edildiği kasabaya gelerek büyük bir coşkuyla çalışmaya başlar. Fakat Aliye Öğretmen güzelliği ile bütün kasabanın dikkatini çekmiştir. Kadınlar ona karşı gizli bir kıskançlık duymakta, kasabadaki erkekler ise özellikle de bölgenin en zengin ailelerinden birisine mensup olan Uzun Hüseyin onu ihtirasla istemektedir. Kasabadaki önemli isimlerden birisi de Hac1 Fettah Efendi'dir. Kuvayımilliye karşıtı olan Hacı Fettah Efendi de Aliye'ye bazı dini gerekçeler ve gizli bir kıskançlık nedeniyle düşmanlık besler. Bir diğer önemli roman kişisi Tosun ise bölgede faaliyet göstermekte olan Kuvayımilliye çetelerinden birisinin reisidir. Aliye ve Tosun birbirlerine âşık olurlar. Uzun Hüseyin Aliye'ye karşı olan ihtirası Hacı Fettah Efendi ise Aliye'nin Kuvayımilliye taraftarı olması ve çocukları zehirleyip kasabadaki uhrevî havayı bozacağı meselelerine kendilerine dayanak yaparak kasabanın yakınlarındaki Yunan karargâhına giderler ve Yunan komutandan kasabayı işgal etmesini isterler. Kasabanın işgalinden sonra Aliye'yi gören Yunanlı komutan da Aliye'ye âşık olur. Aliye kendisine ihtirasla âşık olan bu erkeklerin arasında mücadelesine ve Tosun Bey'e karşı olan bağlllı̆ıına devam eder. İnatla ideali uğruna savaşır, kendisine yapılan ahlaksız tekliflere karşı mukabelesi şiddetle ret olur ve kasabanın işgalden kurtulduğu gün Uzun Hüseyin ve Hacı Fettah Efendi'nin kışkırtmalarılyla taşlanarak öldürülür. Nişanlısı Tosun Bey de Yunan cephaneliğini patlatmak uğruna vücudunun yarısını kaybeder ve gazi olur. Kasabaya gelen Türk birliklerinin kumandanı Aliye'nin ölüm sebebini öğrendikten sonra Hacı Fettah ve Uzun Hüseyin'in bu işte suçlu olduğunu anlar ve Hac1 Fettah ile Uzun Hüseyin'i Aliye'nin öldürüldügü yerde astırarak cezalarını verir. Romanın öyküsü kısaca bu şekildedir. Roman kişilerinin yazar tarafından çizilişi ise Sovyetler Birliği bünyesinde oluşturulan edebiyatlarda çok defa tesadüf edilen olumlu kahraman özelliklerini taşımaktadır:

\section{"Aliye kasabaya muallime olarak geldi. Yü̈zü, henüz açılmayan bir gül goncasmmn mahcup kurmız̨liğmı,

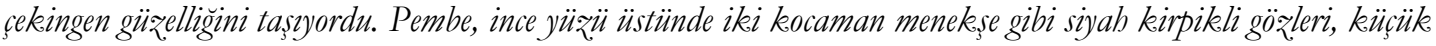 bir çocuk burnu, yü̈zünün bütün bu mütereddit ve cazip inceliğ̈ylyle tez̧at yapan bir narçiçeği goncast gibi garip bir ağ̊ vardı" (Adwar, 2017, s. 21).}

Fizikî olarak kusursuz olan Aliye ülküsü uğruna bir genç kızda olması muhtemel hayallerinden de vazgeçecek kadar romantik ve insanî isteklerinden vazgeçecek kadar sağlam bir karaktere sahiptir. Hiç kimsenin gitmek istemediği Anadolu'ya gönüllü olarak tayinini istemiş, tek gayesini ise karanlıkta kalan Anadolu halkını bilimin ışığı ile aydınlatmak olarak tarif etmiştir. Aliye'yi ve ülküsünü anlamaktan uzak 
kasaba halkı ve özellikle de erkekler Aliye Öğretmen'in karşısına olay örgüsü içerisinde birçok engel çıkaracaklardır ama Aliye'yi bu engellerden hiçbirisi yıldıramayacaktır. Aliye'nin hemcinsi olan Hatice öğretmen ise Aliye’nin ulvî amaçlarına bağlllığı ve ülküsü peşinde yılmaz bir sabırla gösterdiği çalışkanllı̆ııı daha iyi yansitabilmek amacıyla yazar tarafindan fon olarak kullanılmıştır.

"Muallime Hatice Hanmm bu simfa hiç ehemmiyet vermez, ders saatinden ekseri sigarasın yakar, sakızın

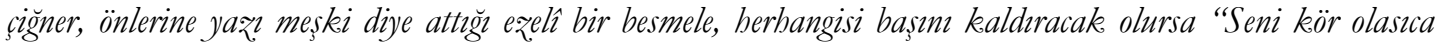
piç!" diye üstüne saldirrde" (Adwar, 2017, s. 30).

Yine Aliye Öğretmen'le ileride nişanlanacak olan Kuvayımilliyeci Yüzbaşı Tosun da Aliye gibi mükemmel özelliklerle donatılmıs "olumlu kahraman” özellikleri taşımaktadır. Tosun adaletli, vatansever, namusu ve ülkesi için canını gözünü bile kırpmadan verebilecek kadar cesaretli ve aynı zamanda mükemmele yakın fiziksel özelliklerle donatılmış bir yalınkatır. "Tosun Karadeniz sahillerinin yetiştirdiği bülend, haşin ve kartal yüzlü, mütehakkim ve güzel bakışlı bir genç yüzbaşı idi.” (Adıvar, 2017, s. 48).

Halide Edip Adıvar'ın olumlu kahramanları yukarıda zikri geçtiği gibi anlatılırken onların bu olumlu özelliklerini daha da belirgin hâle getirebilmek için fon olarak kullanılan çatışmanın diğer tarafindaki yalınkatlar da bir o kadar kötü niyetli, acımasız ve fizikî olarak son derece kötü özelliklerle çizilmiştir. Örneğin kasabaya gelen muallime hanımlara karşı kurduğu tuzaklarla tanınan cinsel açıdan sapık olarak nitelendirilebilecek maarif müdürü:

"Maarif müdürünün toparlak siyah sakah, bulanke sünepe ve mürai gözleri, bilekâr u₹un yür̈̈ altnda iğrenc,

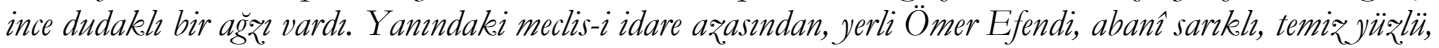
ker sakallı" (Adwar, 2017, s. 25).

Şeklindeki cümlelerle çizilirken aynı paragraf içerisinde Aliye Öğretmen'e evini açarak ona kol kanat gerecek olan Ömer Efendi “temiz yüzlü” ve son derece iyi niyetli birisi olarak çizilmiştir. Aliye Öğretmen’e karşı duymuş olduğu sapıkça sevgiyi yenemeyerek Aliye Öğretmen’i elde etmek emelinden başka bir şey düşünemeyen Uzun Hüseyin bu amacına ulaşabilmek için Yunan askerlerini yaşadıkları kasabaya çağırarak işgal etmelerini isteyecek kadar gözü dönmüş bir âşıktır. Romanda Uzun Hüseyin, "Kendisine dalan iki siyah gözle uzun, sarı, biçimsiz bir yüz, azıcık çarpık, uzun bir burun görünüyordu.” (Adıvar, 2017, s. 33) satırlarıyla neredeyse iğrenç denilebilecek yüz hatlarıyla çizilmiştir.

Yine romandaki Hacı Fettah Efendi de kötü çizilen yalınkatlardan bir diğeridir. Kuvayımilliyecilerin kadınların başörtüsünü çekip aldığı ve dinsiz olduklarını Cuma vaazlarında vererek Kuvayımilliyecilere karşı olan bu kinini Yunan karargâhına giderek Yunan ordusunun kasabayı işgalini ricaya kadar götürmüştür.

"Caminin önünde Fettah Efendi kollarm abdest almak için swąlarken, ay işı̆ğnda nihayetsiz beyaz, ve bombos uzanan meydana baktı. Bulank ve çapakl gözleri kan içinde gülüyordu. İbtiyar dudaklarnin arasinda dökük dislerinden siyah ve bos ağg̨ çirkin bir delik gibi açllyordu" (Adwvar, 2017, s. 72).

Yukarıda uzun uzadıya alıntılarla gösterilen özellikler Jdanov'un 1934 kongresinde 1srarla desteklenmesi ve kullanılmasını istediği olumlu kahramanlar ve onların karşısına çıkarılan olumsuz yalınkatlar şablonuna birçok yönden benzerliği olan sorunlu bir yapıdır. Benzeri tasvirler Kubanıçbek Cantöşöv tarafından 1964 yllında kaleme alınan "Bizdin Sekretar" adlı uzun hikâyede de yapılmıştır.

"Abılkasım yaşı kırka gelmis, kısa boylu, pörtlek koyun gözlü, koca kafah ve yassı suratl yüzü sarıya çalan bir adamdi" (Cantösev, 1964, s. 33).

Komunist kolhozunun başkanı Abılkasım ile genel sekreteri Sagınbek arasında geçen çatışma örgüsünde Abılkasım gençlerin, bilimin ve teknolojik yeniliklerin önünü olabildiğince tıkamaya çalışan, sadece kendi menfaatlerini düşünen ve bütün bu olumsuz meziyetlerinin yanında tembel ve yukarıdaki alıntıda görüleceği gibi son derece abartılı bir çirkinliğe sahiptir. Bununla ilgili örnekleri çoğaltmak mümkündür. Her ne kadar 1934 kongresinden sonra yazılmamış olsa da Özbek edebiyatının ilk örneklerinden sayılan Abdullah Kadiri tarafından kaleme alınan "Ötgen Künler" adlı romanda da olumlu kahramanlara rastlamak mümkündür. Atabey ve Hamid arasında gelişen çatışmanın taraflarından Atabey bir olumlu kahramandır.

"Ağırbaşlı, beyaz çehreli, siyah gözlü, karakaşlı ve pala bıyıklı bir yiğitti." (Kadiri, 2014, s. 12). Çatışmanın diğer kişisi Hamid ise Hacı Fettah Efendi, Maarif Müdür ya da Uzun Hüseyin’e birçok yönden benzerliği olan bir yapıdadır: 
"Diğeri ise uə̧un boylu, esmer, çopur suratl, çakır gö̋lü, sivri sakall, 35 yaşlar civarnda tipsiz, biriydi" (Kadiri, 2014, s. 12).

Yukarıda sırasıyla Türk, Kırgız ve Özbek edebiyatından verilen örneklerde benzeri olumlu kahraman profilleri çizilmiştir. Bu olumlu kahramanların tamamı idealisttir. Önlerine koyulan kutsal amaçları uğruna hiç korkmadan canlarını bile verebilirler. Yorulmak nedir bilmeden gece gündüz çalışabilirler. Atabey acımasız bir yönetici kırbacı altında inleyen soydaşlarını kurtarabilmek için türlü tehlikelere girer ve birçok defa idam edilmekten son anda kurtulur. Ayrıca kadın erkek eşitliğine inanan, evliliklerin aşkla yapılmasını savunan ve evlenmede kadınların da fikrinin alınması gerektiğine inanan ileri görüşlü bir aydındır. Aliye Öğretmen kadınların asla gelmeye cesaret edemeyeceği bir taşra kasabasına tek başına gelmiştir. Tek amacı karanlıklar içerisinde kalan Anadolu halkını bilimin 1şı̆̆ı ile aydınlatmaktır. Bu uğurda önüne çıkan bütün sıkıntılarla çelik gibi sağlam bir irade ile mücadele etmiş ve kendisine şiar edindiği ideali uğruna canını vermiştir. Sagınbek ise sekreteri olduğu kolhozun daha ileriye gidebilmesi için Abılkasım karşısında devrim mücadelesi veren bir idealisttir. Bilime ve tekniğe önem verir. Gençleri yeni metotları ve teknikleri öğrenmeleri için teşvik eder, topluma yön gösteren çelik gibi bir iradeye sahiptir.

Tosun ise kurtuluş mücadelesinin adı bilinmeyen milyonlarca neferinden birisidir. Vücudunun yarısını kaybetmek pahasına Yunan cephaneliğini patlatacak ve savaşın kazanılmasında pay sahibi olacaktır.

\section{Kahramanın İç Dünyasını Açma Meselesi ve Yazarın Eserine Uzaklığı}

Roman incelemelerinde roman kişisini okur nasıl tanıyacaktır sorusuna Peyami Safa "Dünya Romanının Aksaklıkları" (1951) adlı yazısında uzunca bir reçete ile cevap vermektedir.

Bakkalın huyunu bize romancının izahından önce bu kahramanın hadiseler karşısındaki davranışları bildirmelidir... Birçok romanda kahramanın hâl tercümesine rastlarız. Burada da romancı, bize tiyatroyu seyrederken, locadan izahat veren bir adam gibi dışarıdan romanın hayatına müdahale etmiştir (Safa, 2016, s. 234).

Roman kişisi kıskanç, kurnaz, sinirli, dürüst, namuslu ya da yalancı veya bunlardan hepsi birden olabilir. Fakat okur bu özellikleri nasıl görecek ve tanıyacaktır? Bununla ilgili olarak yazarın önünde iki seçenek vardır. Yazar, ya benim filan kahramanım kurnazdır, çirkindir, güzeldir, yalancıdır vs. şeklinde hâkim bakış açısıyla kurmaca dünyasına müdahale edecek ya da kahramanını olay örgüsü içerisinde bir olaya çarptırmak suretiyle onda var olan özellikleri ortaya dökecektir. Ayrıca karakterin okuru şaşırtabilmesi için bir değişim ve dönüşüm sürecinden geçmesi gerekmektedir. Örneğin "Yaprak Dökümü”ndeki Ali Rıza Bey namuslu bir adamdır. Kendine has bir dünya görüşü vardır. Okur, bunu Reşat Nuri Güntekin'in “Ali Rıza Bey namuslu bir adamdır.” şeklindeki tarifiyle anlamaz aksine Ali Rıza Bey olay örgüsü içerisinde trajik bir seçim yapmak zorunda bırakılır ve kişiliğinin bazı yönleri ortaya çıar. Öyle ki çalıştığı şirkete kendisi vasıtasıyla alınan genç kızın şirketin müdürü ile girdiği ahlaksız münasebeti duyunca görevinden geçim sıkıntısına düşme pahasına istifa eder. Fakat romanın ileriki safhalarında kızlarını hem de kendi evinde yabancı erkeklerle dans etmesine göz yumar hâlde bulduğumuz Ali Rıza Bey'in geçirdiği bu dönüşüm sürecine önce sesli direnmesi en başta karısı, kızları ve nihayetinde eve gelen gelinin sert tavırları karşısında geri çekilerek sessiz direnişe dönmesi ve en nihayetinde de eski ve karanlık bir evde bulunarak küçük kızının sevgilisinin yaptığı maddi yardımı kabul edecek duruma gelmesi doğal bir gelişim şeması içerisinde sunulduğu için yadırganmaz. Tasvip etmediği ve birçok insan açısından rahatsız olunamayacak kadar basit bir iliş̧ki yüzünden işinden ayrılacak kadar namuslu Ali Rıza Bey ve kızının sevgilisinin otomobili ile pazar gezilerine çıkan Ali Rıza Bey ikilemi kahramanın geçirdiği doğal değişim süreci bakımından değerlendirildiğinde dikkate değerdir.

Halide Edip Adıvar'n "Vurun Kahpeye" adlı eserinde ise kahramanların iç dünyasını okura sunumdaki yapaylık Aliye ve Tosun üzerinden çok net görülmektedir. Aliye ve Tosun'un aşkları ilk karşılaşmalarında meydana gelir. İkinci karşılaşmaları Aliye'nin Tosun'u yaptığı kötülüklerden vazgeçirmek eğer onu da yapamazsa öldürmek amacıyla Tosun'un odasına hışımla girişiyle olur. Bu ikinci karşılaşmada Aliye ve Tosun gerçekten âşı olduklarına karar verirler. Tosun Aliye'ye hemen oracıkta evlenme teklifi eder. Aliye de kısa bir tereddütten sonra bu âni evlenme teklifini kabul eder. Aliye Tosun'a neden âşı oldu? Erich Fromm, "Sevme Sanatı" adlı eserinde bu duyguyu maddeye indirgemektedir. Buna göre aşk kişilerin birbirlerine verebilecekleri şeylere bağlı olarak oluşmaktadır. Belli satın alma özellikleri ile donatılmış iki kişi bu satın alma gücüne göre pazarda satın alabilecekleri en iyi nesneyi bulduklarına inandıkları gün âşık olmaktadırlar (Fromm, 1995, s.13). 
Tosun bülend boylu, kartal yüzlü ve güzel bakışlarıyla haşmetli bir delikanlı iken Aliye de yüzünde gonca güller açan ve güzelliği herkesin dikkatini çeken genç bir kızdır. Birisi gönüllü öğretmen diğeri ise yine gönüllü bir vatan savunucusu yüzbaşıdır. Bir eksiklikleri yoktur. "Vurun Kahpeye" romanının dünyası içinde göze çarpan bir kusurları bulunmaz. Yeri gelmişken dünya edebiyatında kabul görmüş bir başka esere temas etmek faydalı olacaktır.

Cengiz Aytmatov'un "Cemile" adlı eserindeki Cemile ise genç bir kadındır. Evlidir. Cepheye gidecek olan ekinleri istasyona taşımakla görevlidir. Sovyet edebiyatında o dönemlerde çok görülen olumlu kahramanlardan farklı olarak bu görevde gönüllü olmamıştır. Kitapta Cemile’nin çalışması için izin isteyen görevliye kayınvalidesinin söyledikleri şu şekildedir:

"Olmaz! Allah korkusu yok mu sende? Kadinlarn arabaya çuval yüklemesi duyulmus sey mi?” (Aytmatov, 1996, s. 3).

Cemile ile daha sonra aşk yaşayacak olan Danyar ise cepheden yeni gelmiş bir savaş gazisidir. Bacaklarından birisi aksamaktadır. Annesi, babası ve bir ailesi yoktur. Yüzü de herhangi bir insandan farklı bir özellik taşımayan sıradan bir erkektir.

"Vurun Kahpeye" romanında meydana gelen aşk eyleminin nedenselliği fizikî özelliklere Tosun’un yakışıklılığı ve Aliye’nin güzelliğine dayandırılırken "Cemile"de ise tarafların özellikleri, yaşayacakları trajik ikilemleri güçlendirmek için bir araçtır. Örneğin Aliye'nin Tosun'un kendi kaldığı evde olduğunu öğrendiğinde içten içe Tosun'u görmek istemesi ve daha sonra yaşadıkları şu cümlelerle okura anlatır:

"O, kapı aralğ̈ndan erkeklere görünen her yakışıkl, namdar adam arkasından kosan bir kız, değildi. Hayır, o, isimsiz hayatı bir kahramanlık menkıbesi olan bir Türk zabitinin kızıydı." (Adivar, 2017, s. 28).

Yazarın bu anlatımında eleştirilen konu kahramanın iç dünyasını okura gösterecek tetikleyici bir olayla bu durumun doğal ve tutarlı bir şekilde okurun önüne serilmesi yerine bizzat hâkim bakış açısıyla kahramanına ve olay örgüsüne müdahale ederek kurmaca dünyası ile arasında olması gereken uzaklık sınırlarını aşmasıdır. "Aliye öyle bir kadın değildir, Aliye böyle bir kadındır." söylemi ortaya güzelliği gibi iç dünyası da yapay olarak çizilmiş bir Aliye çıkarmaktadır. Cemile romanında ise başkişi Cemile evli bir kadındır. Ayağı aksak bir adama âşık olacak ve onunla kaçacaktır. Bizim dünyamızdan bakıldığında Cemile bir hafiflik yapmış ve toplum içerisinde kabul edilen evli kadın çizgisinin dışına çıkmışır. Fakat Cemile romanının kurmaca dünyası içerisine girdiğimizde Cemile ve roman kişilerinden Osman arasında geçen bir olay Cemile'nin esasında nasıl bir kadın olduğunu okuruna anlatan yazarın maharetini gözler önüne serer:

"Ot bicme zamanydl, bir gün Osman, Cemile'ye sarkintllk etmeye kalkışt. Bu çocuk uz̧aktan akrabamız. olurdu. Hiçbir kadmon kendisine direnemeyeceğini sanan erkeklerden biriydi. Cemile onun elini biddetle itti, gölgesinde dinlendiği dokurcunun altundan kalkarak öfkeyle bağgrdl:

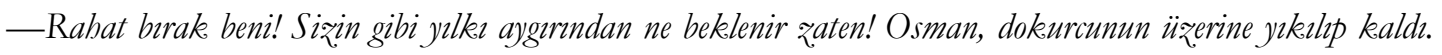
Islak dudaklarm nefretle bükerek:

—Kedi erişsemediği ciğere murdar der. Niye cilve yapıyorsun? Aslnda için gidiyor, arzudan kuduruyorsun ama yine de burun kivrryorsun.

Cemile birden döndü:

— Belki içim gidiyordur, kader ölle yapmus ve sen dalga geçiyorsun ama şunu bil ki, sersem kafa, yüz yll asker karıs olarak kalsam, senin gibi ï̆renç bir adamm yü̈züne bile tükeürmem! Savas olmasaydı görürdün sen gününü (Aytmatov, 2017, s. 20).

Cemile'nin kendisine şehevi duygularla saldıran Osman karşısında tutunduğu tavır Cemile karakterini okura tanitan olaylardan birisidir. Aytmatov da kendi kurmaca dünyasında Cemile'yi Adivar'ın Aliye'ye yaptığı müdahale örneğinde olduğu gibi anlatabilir, onu gönüllü olarak cepheye ekin taşıyan arabalarda çalıştırabilir ve namus timsali eski bir zabit kızı olarak çizerek neticede Danyar’a duyacağı aşkı da Danyar'ın bülend boyuna, kartal yüzüne ve etkili bakışlarına bağlayabilirdi. Fakat roman kişisini bir duvara çarptırarak oluşacak olan etkiyle iç dünyasını açmak ve bu iç dünyayı tutarlı bir örgü içerisinde okurun gözleri önüne sermek E. M. Forster'in "Roman Sanatı" adlı eserinde belirttiği okurda olması gereken bellek konusuna çok iyi bir örnektir. Buna göre olayların sıralanışının zamansal açıdan bir önemi olmasa da olay örgüsüne yaptıkları hizmet ancak olay örgüsünün ileriki safhalarında anlamlandırılabilecek bir bellek talep eder. Geriye dönüp baktığımızda önemsiz gibi görünen olayların esasında ne işe yaradıklarını okuyucu belleği sayesinde anlar (Forster, 2001, s. 131). 
İkinci Dünya Savaşının Kırgız tarihinde önemli bir yeri vardır (Buyar, 2017, s. 84). Aytmatov bu dönemde kendi gözleriyle savaşı ve cephe gerisinde açtığı yaraları gözlemlemiştir. Bazı yazarlar yaşadıklarını önemli ve anlatılmaya değer buldukları için eserlerinde kendilerini gizlemeye gerek görmeden romanlarına konu yaparlar (Aşlar, 2015, 85). "Vurun Kahpeye" ve "Cemile" romanlarının karşılaştırılması bu açıdan da değerlidir. Hem Aytmatov hem de Adıvar kendi gözleri ile gördüklerini eserlerine yansıtmıştır.

Olay örgüsü içerisinde Aliye ve Tosun'un aşklarını ilanı ile Cemile ve Danyar'ın yaşadıklarını karşılaştırmak hem tutarlılık hem de iç dünya açma meselesine yazarların yaklaşımını göstermesi açısından önemlidir.

Aliye hışımla Tosun'un bulunduğu odaya girer. Amacı kasabaya yaptığını düşündüğü haksızlıklardan dolayı Tosun Bey’i uyarmak eğer bu da fayda etmezse onu öldürmektir.

"-Bu toprak benim toprağım, bu kasaba benim kasabam, bunu sev, bunu mubafaza et, dedi. Bir an kesilen nefesini fissldar gibi ilave etti:

-Istedig̈in zaman seninim, istediğin yolda yürürüm.

Iki ates gibi, bir kü̈gük an içinde, dudaklar birbirini yaktı, ikisinin rubuna da ates damgası bastı ve ayrldalar." (Adwar, 2017, s. 68).

Yukarıda az evvel kapı aralarında kendini göstermeyen namuslu bir zabit kızının kavga etmeye geldiği adamın odasında aldığ ani evlilik teklifi karşısında kısa bir tereddütten sonra önce bu teklifi kabul etmesi sonrasında da teklif sahibini ateşli dudaklar marifetiyle öpmesi hem olay örgüsü içerisinde tutarlllık kavramını zorlamakta hem de kahramanın iç dünyasını açma konusunda tetikleyici bir olay yokluğu bu romantik sahneye suni bir görünüm kazandırmaktadır. Benzer sahne için karşılaştırma açısından Cemile'den yapılacak olan alıntı yerindedir:

Ama bu defa Danyar'a bir şeyler olmustu: Türküsünde ölle tath, öyle dokunakl bir sevecenlik ve öyle bir

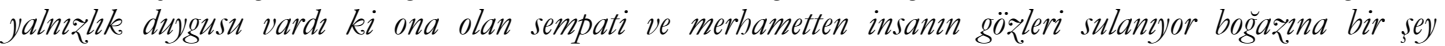
takilhyordu. Cemile başı önde yürüyor ve arabanın korkuluğunu simsıke tutuyordu. Danyar'n sesi tekrar yükselince basıın kaldird, sçrayip Danyar'in arabasina bindi ve onun yanina oturdu. Elini göğsïne koymus ve sanki tas kesilmiști. Ben arabann yaninda yürïyor, hafifge hrzlanarak öne geçiyor ve göz ucuyla onlara bakeyordum. Danyar sanki yannda Cemile'nin varhğmn hissetmemis gibi söylüyordu türküisünü. Cemile'nin kollar mecalsiz yere dïsmüstü yine. Danyar'a iyice sokulmus, "bassım bafifge onun omzuna dayamıstt." Bir an kurbac yiyen atun birden sıçraması gibi, Danyar'm sesi titredi, sonra yine bir kuvvetle yine gürledi, çınladr. Danyar șimdi bir aşk türkëisü söylüyordu. Ben allak bullak olmustum. Bozker birden çiçeklenmis, kumuldamıs, karanliklar kovmustu sanki. Ve bu engin bozkerda ben iki asşlk görmüstüm. Beni fark etmiyorlardı bile. Sanki ben orada değildim (Aytmatov, 2017, s. 60).

Yukarıda yapılan alıntıda artık paçavraya dönmüş bir asker kaputu giyen ayağı aksak bir adamla Cemile'nin ilk fiziksel temaslarında genişlik algısını oluşturmak için bozkır ve çiçek imgelerinin kullanımı ve mekânın olayı tamamlayışı dikkate değerdir. Diğer taraftan ortada yine fizikî bir istismar yoktur. Gerçek ve içten olan aşkı, ateşli dudaklarla öpüşmek eyleminde çok daha etkili anlatan başı omza koyma eylemi mevcuttur ve romanın içerisinden gelen müzik son derece etkileyicidir. Fakat uzunca sürdüğü belli olan bir iç muhasebe döneminden sonra sosyal normlara rağmen Cemile’nin verdiği kararda olay örgüsü içerisinde olayların sıralanışında ve bağlanışındaki doğallık Aliye ve Tosun Bey örneği fon olarak kullanıldığında net bir şekilde ortaya çıkmaktadır. Yeri gelmişken evli bir kadının hem de kocası cephede savaşırken başka bir adama âşı olup onunla kaçması eyleminin tasvip edilecek bir yönünün olmadığını belirtmek durumundayız. Burada tartışılan "Cemile" romanının kurmaca dünyası içinde ortaya konulan sanattır. Cemile'nin yaşadığı ikilem örf-âdet ve sosyal toplumun evli kadına yüklediği anlamla gerçek aşk arasında yaşanırken ne Aliye'nin ne de Tosun'un trajik bir seçim yapmak zorunda kalmadan yazarın önlerine koyduğu amaç doğrultusunda kararlılıkla gitmeleri Adıvar'ın kurmaca dünyasına yaptığı açık müdahaleden kaynaklanmaktadır. 


\section{Belirtik Hakikat ve Örtük Hakikat}

Edebî eserlerde belirtik hakikat ve örtük hakikat konusu Sosyalist Realizm eleştirilerinde çok kullanılan tartışmalı bir konudur. Estetikçiler ve eleştirmenler tarafından tartışma konusu olan edebiyatın hakikati yansıtma görevinin olup olmadığı konusunda edebiyat dünyasında tartışmalar vardır. Belirtik hakikat ve örtük hakikat kavramlarını en iyi ifade eden olay Bertolt Brecht'in "Yiğit Ana ve Çocukları" adlı oyunu etrafinda yaşananlarla anlaşılabilir. Savaştan nemalanan, bir şekilde savaşı kendi yararına faydacı bir yapıda kullananları eleştirmek isteyen Brecht, Otuz Yıl Savaşları sırasında İsveç ordusunun peşinden giderek askerlere giyecek, ayakkabı ve içki satan bir kadının hikâyesinin anlatıldığı "Yiğit Ana" adlı bir oyun kaleme almıştır. Savaştan sağladığ faydanın kötülüğü üzerinde düşünmeden işine devam eden Yiğit Ana'nın iki oğlu ve bir kızı yine savaş sebebiyle ölürler. Yiğit Ana ise ordunun arkasından giderek ticaretine devam eder. Brecht’in ortaya koyduğu amaç Yiğit Ana'nın kötülüğünü göstermekken Zürih’teki ilk gösterimde seyirciler bu durumu farklı yorumlamış ve kadının başına gelenlere acıyarak ağlamışlar. Brecht, ortaya koyduğu amacı daha iyi yansıtabilecek birkaç değişiklik yapar ama Doğu Berlin'deki gösterim de Brecht'in istediği sonucu sağlamaz. Bazı Komünist parti yetkilileri "Yiğit Ana"nın oyunun sonunda hatasını anlayarak halka bir şeyler söylemesini ve oyunda belirtik bir komünist tezin yer almasını teklif etmişler. Ama Brecht bunu kabul etmemiştir (Moran, 1988, s. 232). Brecht'in parti yetkililerinin teklifini kabul etmemesinde belirtik hakikatin eserinin sanat değerini düşüreceği korkusu çok açıktır.

"Vurun Kahpeye" adlı eserdeki imgelere bakıldığı zaman Brecht’in kaçındığı açık hakikatin Adıvar'ın romanının genelinde net bir şekilde görüldüğünü söylemek yanlış olmaz. Romandaki en etkin kötü kişi Hacı Fettah adında bir cami hocasıdır. Fettah Allah'ın isimlerinden birisidir. Çatışmadaki taraflardan Uzun Hüseyin ile birlikte fon olarak kullanılmaktadırlar ve hem Aliye'nin hem de Tosun Bey'in iyiliklerini, güzelliklerini kalplerindeki temizliği gösterebilmek için olabildiğince kötü çizilmişlerdir. Bu şema Sovyetler Birliği edebiyatlarında komünist tezi açık bir şekilde savunan edebî eserlerde çok rastlanılan bilindik bir şemadır. Stalin'in ölümüne ve Kruşçev'in parti genel sekreteri olduktan sonra Komünist Partisi XX. Kurultayında yayımladığı mektuba kadar devam eden bu süreçte genellikle çatışmanın taraflarından birisi moldo şeklinde tabir edilen din adamları ya da manap şeklinde tabir edilen feodal zenginlerden oluşurdu. Bu bahsi geçen moldolar ya da zengin toprak ağaları komünizm ideasını romantik bir şekilde yaşayan ideal olumlu kahramanın karşısına çıkar ve gizemden uzak sıkıcı bir şema oluşurdu. Okur üzerinde estetik yaşantı uyandırma amacı gütmeyen bu tip eserlerin yazılış amaçları belirtik olduğu için ortaya konulan idea da net bir şekilde komünist söylemlerden ibaret olurdu. Bu şema 1934 yazarlar birliği kurultayından Stalin'in ölümüne kadar hemen hiç değişmeden birliğe bağlı bütün yazar birlikleri üyeleri tarafindan kullanılmıştır.

"Vurun Kahpeye" romanında da açık bir şekilde belirtik hakikat mevcuttur. Abdest, İslam dininde bir arınma ve temizlenme ibadeti iken Hacı Fettah Efendi’nin abdest alırken kafasındaki düşüncelerin yüzüne akis şekli neredeyse bir korku filmini andırmaktadır. Yine Cuma namazı öncesi cami önünde toplanan cemaatin yazar tarafindan ellerinde bayraklarla meydanda marş söyleyen Aliye Öğretmen’in öğrencilerine fon olarak kullanılması ve şu cümlelerle tasvir edilmesi manidardır.

"Orada sessizlikle duran siyah kütle, içine isimsiz, bir eza veriyor, müphem bir şekilde korkutuyordu." (Adivar, 2017, s. 21).

Bir din adamı olan Hacı Fettah Efendi'nin Cuma namazı sonrası halka yaptığ vaazda Kuvayımilliyecilerin kanının helal olduğunu açık bir şekilde vaaz etmesi ve kendi şahsî hırsları yüzünden Yunanlıları kasabayı işgale davet etmesi Hacı Fettah Efendi’nin iç dünyasında bir nebze olsun kabul edilebilir insanî bir zayıflık olarak görülebilirdi. Ama yazarın Hacı Fettah Efendi'nin bu davranışlarını din ile ilişkilendirmesi ve Cuma namazı sonrası meydanda toplanan kalabalığı siyah kütle olarak nitelendirmesi ve bu siyah kütlenin Aliye'ye verdiği müphem korku yine yazar ve eser arasında olması gereken mesafenin ihlali ve Brecht'in 1srarla kaçındığı belirtik hakikat unsurunun esere net bir yansıması olmuştur.

Cemile'de ise belirtik hakikat yoktur. Nitekim "Cemile" Stalin dönemi toplumcu gerçekçiliğe karş1 tepki olarak Kırgız edebiyatında yazılan ilk eserlerden birisidir. Önce insanî bir duygu olan ölüm korkusunu savaştan kaçma eylemine dayanak yapan İsmail'in başkişisi olduğu "Yüz Yüze" sonra da kocası savaşta olan genç bir kadının yine insanî bir duygu olan aşka tutulmasını anlatan "Cemile" örneklerinde görüleceği üzere Aytmatov olması gerekeni değil var olanı yansıtmıştır. Bu da Jdanov'un 1934 yazarlar kurultayında temellerini attığı "toplumcu gerçekçi" kuramın yeniden yorumlanması anlamına gelmektedir ki bu bir edebî devrin kapanışı ve bir yenisinin açılışı anlamına gelmektedir. 


\section{Tartışma, Sonuç ve Öneriler}

"Vurun Kahpeye" adlı romanın sonu etkileyicidir. Aliye'ye hak etmediği sonu Hacı Fettah ve Uzun Hüseyin hazırlamışlardır. Yani roman geleneğimizde kendisine yer edinen dini kendi bencilce isteklerine alet eden hoca tipi, olumlu kahramanın sonunu hazırlamısstır. Ancak burada bile olaylar bir resmin canlılığını geçmemekte, Aliye bir oldubitti ile taşlanarak öldürülürken bir anda kasaba kurtulmakta ve Aliye'nin katilleri yine alelacele cezalarını bulmaktadır. Esasında olay örgüsü içerisinde işlendiğinde sarsıcı özellikler katabilecek birçok trajik unsur varken zamansal bir sıra ile her şeyin aceleyle yapilması romanı sarsıcı olmaktan çıkarmıştır. Aliye'nin hak etmediğini düşündüğümüz bir cezaya çarptırılması sadece Hoca tipinin kötülüğünü ön plana çıkarabilmek için Aliye'nin fon olarak kullanılmasından başka bir şey değildir. Bu da açık bir kolektif bellek çalışmasıdır.

Temas edilmesi gereken bir başka nokta da Aliye ve Tosun'un aşklarının kuvvet noktasıdır. Bir ağacın altında buluştukları gece Aliye nişanlısı Tosun'a, Hacı Fettah Efendi'nin hıyanetini, Uzun Hüseyin'in edepsizliğini ve Yunanlı komutan Damyanos'un ahlaksız amacını anlatmış ve nişanlısından kendisini bu kasabadan alıp kaçırmasını yalvarırcasına istemişti. Tosun'un bu anlatılanlar karşısında derin bir trajediye batması ve en azından bir duygu yoğunluğu yaşayarak tercihini vatan savunmasından ya da sevdiği kadından yana kullanması beklenirdi. Fakat Tosun Bey'in iç dünyasında:

\section{"Allahaısmarladlk Aliye, korkma, seni ben biliyorum. Dünyann en kavi kumandanu sana bir fenalı yapmaya kadir değildir, haydi yavrum git." (Adwar, 2017, s. 156).}

Sözleriyle işgal altındaki bir kasabada sevdiği kadının bedenini istismar etmek isteyenler var olduğu gerçeğinin trajedisini yaşamaması inandırıcılık ve açıklanabilirlikten uzaktır.

Örneğin çocukları ve eşi ile inandığı ahlaki değerler arasında kalan adamın iç muhasebesi ve direnişini bize son derece sarsıcı bir şekilde yansıtan "Yaprak Dökümü” (Güntekin, 2002), ya da evli ve kocası savaş meydanında savaşan bir kadının sosyal öğretiler ve aşk ikilemi içerisinde kalışını anlatan "Cemile" bu açıdan bakıldığında çok daha etkileyicidirler. Fakat hem Aliye'nin hem de Tosun Bey'in görünüşleri gibi aşkları da öyle cansızdır ki kitabın en sivrilen kişisi doğal olarak kötülükte sınır tanımayan ve abdestli elleri ile Aliye'nin boğazına sarılması an meselesi olan Hacı Fettah Efendi'dir. Zaten kitapta en son ölümün Hac1 Fettah'a ayrilması doğal olarak merkeze Hacı Fettah Efendi'yi itmektedir. Hâliyle bu durum Aliye ve Tosun Bey’in onun kötülüklerini göstermek için karşılarına çıkarılmış iyi özellikli fon kişileri oldukları intibainı uyandırmaktadır.

Bütün bunların yanında memleketim ve kadınım ikileminde kalmayan Tosun'un bu konuyu kendi iç dünyasında daha trajik bir hesaplaşma ile çözmesi beklenirken soğuk bir resim gibi hareket etmesi de yine tipik bir olumlu kahraman davranışıdır ve bu durum Tosun'u tek boyutlu bir resim olmaktan kurtaramamıştır.

"Vurun Kahpeye" de belirtik hakikat bütün unsurları ile ortadadır. Yani eserin yazılış amacı ve kurmaca dünyanın nedenselliği bellidir. "Olumlu kahramanlar" bu nedensellik üzerine kurulmuş olay örgüsü zemininin kuklaları konumundadır. Yazar hem Aliye'yi hem de Tosun'u kendi belirtik hakikatini daha iyi gösterebilmek için çizmiş ve belli bir dönem Sovyetler Birliği edebiyatlarında da olduğu gibi asgari ölçülerde dahi sanat kaygisı gütmemiştir.

\section{Kaynakça}

Adıvar, H. E. (2017). Vurun kahpeye. İstanbul: Can Yayınları.

Aşlar, H. (2015). Modern kırgız edebiyatında biyografik roman türünün tarihi gelişimi üzerine. Turkish Studies, Volume $10 / 4$

Aytmatov, C. (1996). Cemile, ögretmen duyssen (Çev: Ülkü Tamer). İstanbul: Adam Yayınları.

Aytmatov, C. (2017). Cemile (Çev: Refik Özdek). İstanbul: Ötüken Neşriyat Anonim Şirketi.

Belge, M. (1998). Edebiyat üzerine yažlar. İstanbul: İletişim Yayınları.

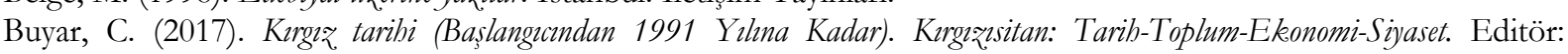
Cengiz Buyar, Bişkek: BYR Publishing House.

Cantöşev, K. (1964). Biədin sekretar. Frunze: Mektep.

Dobrolyubov, N. A. (1987). Oblomovluk nedir (Çev: Mazlum Beyhan). İstanbul: Yön Yayınları.

Forster, E. M. (2001). Roman sanatı (Çev: Ünal Aytür). İstanbul: Adam Yayınları.

Fromm, E. (1995). Sevme sanatı. (Çev: Yurdanur Salman). İstanbul: Payel Basın-Yayınevi.

Gorki, M. (2011). Sanatta sosyalist gerçekesilike. (Çev: Feyyaz Şahin). İstanbul: Parşömen Yayınları.

Güntekin, R. N. (2002). Yaprak, dökïmü. İstanbul: İnkılap Kitapevi. 
Jdanov, A. A. (1934). Pervyy vse soyuznyy się̧d sovetskih pisateley. Stena Grafiçeskiy Otçet. Moskva: Gosudarstvennoe İzdotelstvo (Hudocestvennaya Literatura).

Jdanov, A. A. (1952). Daklad o jurnalah zvezda i leningrad. Moskva: Gosizpolit.

Kadiri, A. (2014). Ötgen künler (Çev: D. Ahsen Batur). İstanbul: İleri Yayınlar1.

Karataș, T. (2018). Ansiklopedik edebiyat terimleri sözlïğ̈̈u. İstanbul: İz Yayincilık.

Moran, B. (1988). Edebiyat kuramlar ve elestiri. İstanbul: Cem Yayınevi.

Platon (2018) Devlet (Çev: S. Eyüboğlu ve M. A. Cimcoz). İstanbul: İş Bankası Kültür Yayınları.

Safa, P. (2016). Sanat, edebiyat, tenkit, objektif 02. İstanbul: Ötüken Neşriyat.

\section{EXTENDED ABSTRACT}

In this work, the novel "Vurun Kahpeye" written by Halide Edip Adivar: positive heroes, specific and implicit truth, the inner world of the protagonist and the author's work in terms of the distance was discussed and in this process the work was compared to the Cengiz Aytmatov's novel Cemile. At the same time examples from Uzbek and Kyrgyz literature are given and the differences between the term defined as type in Turkish literature and the term defined as positive hero are emphasized.

Positive heroes are at the center of the fictional world. Positive heroes have their own characteristics. They are exposed to a degree to be envied by the author. They come up with a perfect posture in terms of physical characteristics and morality. Types can have different characteristics. They may be physically and morally flawed. They do not have a specific ideal; they do not act for a purpose. In this article, a study has been done by giving examples of the above-mentioned works in order to better understand the positive heroes. The emergence of positive heroes and the realm of socialist realistic literature were analyzed. The first example of that its Plato's State. On the subject of moral slavery, the role of Oblomov, the work of Ivan Gonçarov, in the emergence of positive heroes and his role in literature is emphasized. In this case, the emergence and distribution of Oblomovism disease in Russian literature is examined. In this section, criticism of the socialist realist Jdanov, who describes critical realistic literature as a literature that is not in harmony with society, has been included.

Halide Edip's Vurun Kahpeye is selected and examined for the existence of positive heroes in Turkish literature. Aliye teacher, who was assigned to an Anatolian village, was considered as a positive hero. Aliye Teacher, Hac1 Fettah and Uzun Hüseyin were put in this work of him to make more positive roles by the author. In this section, Aliye went to the village where she was teaching, her stance on not giving up this will. This is an example showing us that there are positive heroes in Turkish literature. These contradictions are seen in the long story of the Bizdin Secretary written by Kubaniçbek Cantöşöv, the writer has equipped Abyskim with a bad physical face, short, flat face and a big head. Atabek from Uzbek literature of Abdullah Kadiri's novel Ötken Künler was chosen as a positive hero and there was a conflict between Hamid, who was physically badly equipped. In the works given, it is concluded that Aliye Teacher, Saginbekist, and Atabek are idealistic heroes who act in the direction of Tosun who were fighting for the liberation struggle and the cost was of losing half of his body.

The question of opening the inner world of the hero and his distance from the author's work are given by comparing the Works of Reşat Nuri Güntekin's Yaprak dökümü, Halide Edip Adıvar's Vurun Kahpeye and Cengiz Aytmatov's Cemile. In this context, Ali Riza Bey's resignation from his wife, daughters and daughter-in-law was discussed.

Ali Riza Bey, who did not tolerate immorality at work was paying the of being unemployed. He was still silent against the bad behavior of his daughters, especially the bad attitude of his bride. Ali Riza Bey's dilemma, which goes on Sunday trips with his daughter's lover's car, goes further and the process of a natural change of the hero get explained. Secondly, the subject of artificiality in reflecting the inner world of the heroes in Vurun Kahpeye is studied. The love between Aliye and Tosun was created in the first encounter. In the second encounter they realize that their interest in each other is a real love. Author made them love each other without any emotional link between heroes. Under the view of positive heroes, the two people are extremely perfect heroes, making them impeccable in the inner world of the novel. Tosun is a tall, nice faced, beautiful-eyed young man. Aliye is a girl who attracts attention with her beauty. Both heroes do not have a noticeable deficiency.

Cengiz Aytmatov in his work Cemile: Cemiles husband is a man who is in the military. It's a love story is revealed during the transport of the crops that will go to the front. The difference of Tosun in Vurun Kahpeye, one of his legs is a clunky Danyar. By comparing the two works, the difference between the real love and the natural way is clearly seen. By Vurun Kahpeye the element that triggers love is a tool 
to strengthen the tragic dilemmas of the parties in Cemile while the physical features. In this novel, it is claimed that Cemile, who had run away with a limp man, had a lightness in social lines. As a result, Cemile is a married woman, and her husband is in the military. However, when we enter the inner world of the novel, a case between Cemile and Osman will show us that Cemile is not a mildly ill woman. Aytmatov has drawn Cemile's inner world by drawing on a different perspective and blowing it against a wall with environmental effects and this inner world is placed in the eyes of the reader with a consistent plot. When these two novels are compared, the differences will be seen clearly in terms of explaining the differences between the authors. While Halide Edip's physical touches were at the forefront, Aytmatov worked on this by emphasizing it has emphasized its impact of the case.

The explicit and implicit truth in novels is a controversial concept by critics and aesthetists. In this case, Brecht's "Mother Courage and Her Children" work has been examined. It was criticized that the clear truth that Brecht avoided was clearly reflected in Vurun Kahpeye. Hac1 Fettah Uzun Hüseyin such as Aliye and Tosun more clearly revealed by this work Vurun Kahpeye has tried to reach a judgment in terms of art value. 